\title{
Earnings Smoothing as Information Signaling or Garbling: A Review of Literature
}

\author{
Nor Afifah Shabani (Corresponding author) \\ Department of Accounting and Finance, Faculty of Management \\ Universiti Teknologi Malaysia, 81110 Johor, Malaysia \\ E-mail: norafifah85@gmail.com \\ Saudah Sofian \\ Department of Accounting and Finance, Faculty of Management \\ Universiti Teknologi Malaysia, 81110 Johor, Malaysia \\ E-mail: saudah@utm.my
}

Received: March 6, $2018 \quad$ Accepted: March 27, $2018 \quad$ Published: June 1, 2018
doi:10.5296/ajfa.v10i1.12768 $\quad$ URL: https://doi.org/10.5296/ajfa.v10i1.12768

\begin{abstract}
Earnings smoothing, which refers to the action of managers managing earnings to reduce fluctuations of reported earnings, is a special type of earnings management because while earnings smoothing may be used to distort shareholders and creditors' view of corporate actual performance, it may also serve as a tool to communicate corporate private information of future earnings to the aforementioned stakeholders. Hence, it comes to no surprise when prior literatures reveal that the studies on the role of earnings smoothing are divided into two streams: as information signaling and information garbling. This paper aims to review prior literatures, specifically on the role of earnings smoothing either as information signaling or garbling based on four themes: firm value, financing need, compensation contract and outsiders' intervention. This paper reviews journal articles gathered from Web of Science database. Based on the shortcomings of prior literatures, this paper highlights avenue for future research.
\end{abstract}

Keywords: earnings smoothing, information garbling, information signaling, firm value, financing need, compensation contract, outsiders' intervention 


\section{Introduction}

Earnings smoothing, which refers to the action of managers managing earnings to reduce fluctuations of reported earnings, is a special type of earnings management because while earnings smoothing may be used to distort shareholders and creditors' view of corporate actual performance, it may also serve as a tool to communicate corporate private information of future earnings to the aforementioned stakeholders (Dechow et al., 2010; Goel \& Thakor, 2003). Although most studies generally use earnings smoothing as a proxy for earnings management (Bhattacharya et al., 2003; Burgstahler et al., 2006; Leuz et al., 2003), some studies find that earnings smoothing in fact is associated with improved earnings quality (Ewert \& Wagenhofer, 2015; Shubita, 2015; Subramanyam, 1996; Tucker \& Zarowin, 2006). Hence, it comes to no surprise when prior literatures reveal that the studies on the role of earnings smoothing are divided into two streams: as information signaling and information garbling.

The role of earnings smoothing as information signaling is usually associated with managers' motivation to improve firm value (Di \& Marciukaityte, 2015; Graham et al., 2005; Shuto \& Iwasaki, 2014), and to achieve lower cost of debt from creditors (Dou et al., 2013; Gassen \& Fülbier, 2015; Li \& Richie, 2016). Based on the view of earnings smoothing as information signaling, managers who have private information about firm's future earnings and yet are not allowed to directly disclose the information to outsiders (shareholders, creditors and other stakeholders), may convey the private information through bias reported earnings, to maximize firm's value (Sankar \& Subramanyam, 2001). In addition, using managers' discretion, as allowed by the generally accepted accounting principle (GAAP), managers would choose to present a smoother earnings stream to signal the stability of the firm's underlying earnings process. In turn, the firm's cost of borrowing is reduced as creditors lower their assessment of the probability of firm's bankruptcy, and hence increases firm's value (Trueman \& Titman, 1988).

On the other hand, earnings smoothing is viewed as information garbling when earnings smoothing distorts information and consequently leads to higher information opacity. Bhattacharya et al. (2003) argue that earnings smoothing resulted in reported earnings not depicting the true underlying economic performance of the firm, and hence reducing the informativeness of reported earnings and increasing information opacity. Earnings smoothing as information garbling is usually associated with managers' concerned on compensation contract (Das et al., 2013; Defond \& Park, 1997; Grant et al., 2009) as well as to avoid outsiders' intervention in management (Acharya \& Lambrecht, 2015; Khurana et al., 2017).

Managers boost earnings during bad times, to lengthen their job tenure, or to reduce earnings during good times, to save for future bad times (Fudenberg \& Tirole, 1995; Lambert, 1984). Further, asymmetric information theory argues that investor's estimate is unbiased and 'best' based on the information they have. Therefore, it is considered rational for shareholders to require earnings outcome that is consistent with their expectation (Acharya \& Lambrecht, 2015; Kirschenheiter \& Melumad, 2002). Accordingly, managers have to report an earnings figure that corresponds to outside shareholders' expectation rather than true income, to avoid 
outsiders' intervention. Specifically, during bad times, managers use smoothing to conceal unfavourable earnings realizations and create reserves for future periods by understating earnings during good times (Acharya \& Lambrecht, 2015; Khurana et al., 2017). Generally, investors give managers the benefit of the doubt and perceive low risk when earnings are relatively smooth. However, when additional information suggests that managers have incentives to garble information, they no longer give managers the benefit of the doubt (Erickson et al., 2017).

Studies related to earnings smoothing have been around for more than six decades. However, the recent decades show the most development with more than 80 percent of studies in this field was published after year 2000. Following Hepworth's (1953) note that firms with smooth earnings signal stable corporate management to the shareholders and creditors, the study on corporate earnings smoothing has evolved ever since. Until recently, scholars have been trying to prove the existence of earnings smoothing activities (Beidleman, 1973; Boterenbrood, 2014; Khalil \& Simon, 2014), figuring how (Atik, 2009; Francis et al., 2016) and when (Gassen et al., 2006; Gill de Albornoz \& Alcarria, 2003) managers smooth earnings, characterizing earnings smoothing firms (Bigus et al., 2016; Bouwman, 2014; Z. Huang \& Xue, 2016; Safdar \& Yan, 2016; Silhan, 2014), and most importantly understanding the motivation (Goel \& Thakor, 2003; Lambert, 1984; Trueman \& Titman, 1988) and consequences (Houcine, 2017; Shubita, 2015; Tucker \& Zarowin, 2006) of such behavior.

This paper aims to review prior literatures, specifically on the role of earnings smoothing. Based on the discussion of the past literature, this paper also makes some suggestions for future research. To achieve these objectives, this paper reviews journal articles published in Web of Science database. A broad search was initiated based on the keywords used for the title. The literature of earnings smoothing is divided into 2 categories: (1) banks and (2) other business sectors. Since the regulations between banks and other sectors are governed by different policies (banks are governed by BAFIA Act while other firms are governed by Companies Act), the financial reporting practices between these firms are significantly different. Hence, this paper chooses to focus only on smoothing behavior in the latter category. In addition, the paper also does not review papers on dividend smoothing.

\section{Accruals and real smoothing}

Smoothing can occur through accounting accrual (also known as artificial) and real smoothing activities. Accrual smoothing, which refers to the accounting choices that usually occur at the end of the fiscal year, change reported earnings without changing the underlying cash flows. Examples of accrual smoothing include adjusting reserves for losses, delaying or forwarding the recognition of revenue and expenses, and reclassifying the expense items into capital accounts. Meanwhile, real smoothing activities usually occur throughout the fiscal year, by which managers change its operation. Examples of real smoothing activities include altering shipment schedule, offering end-of-period sales, and speeding up or deferring maintenance (Fudenberg \& Tirole, 1995; Lambert, 1984). Generally, managers utilize income-increasing smoothing to boost revenue when expected earnings fall short the desired threshold, and income-decreasing smoothing when expected earnings is greater than the 
desired threshold (Sankar \& Subramanyam, 2001).

Overall, most studies which examine earnings smoothing as information signaling or garbling, measure earnings smoothing using accrual smoothing instead of real smoothing. Only very few studies measure earnings smoothing using real smoothing, such as Dhole et al. (2016), Francis et al. (2016), Huang et al. (2009) and Khurana et al. (2017). Therefore, this section is contributed to the studies that examine real smoothing activities while the rest of the paper i.e. from section 2.1 until 2.4 discuss the roles of both real and accrual smoothing activities. Except for studies mentioned in this section, all studies mentioned from section 2.1 until 2.4 use accruals as their earnings smoothing measurement.

Based on the view that earnings smoothing is used to garble information by managers, Khurana et al. (2017) find positive association between real earnings smoothing and firm-specific stock price crash risk. Real earnings smoothing allows managers to conceal firm's actual performance. Therefore, when the accumulated bad news bubble burst, stock price crash as a result of investors' negative reaction. Francis et al. (2016) also find that firms engage in downward real earnings management to garble information. Managers manage earnings downward immediately before share repurchases, management buyouts and CEO option awards to lower the stock prices, for their private benefits. In similar vein, Dhole et al. (2016) find that CEO incentives to smooth earnings (due to garbling role) through both artifical and real earnings management is mitigated via CEO inside debt (debt-like component of executive compensation such as deferred compensation and pensions).

However, using derivatives as the measure of real earnings smoothing, Huang et al. (2009) find that real earnings smoothing is less pronounced in firms with weak governance, showing that real earnings smoothing does not serve as information garbling. Instead, they find evidence that derivaties (real earnings smoothing proxy), serves as information signaling and add greater value to firms with weak investor protection. They argue that derivatives have been used to eliminate extraneous shocks and hence improve the informativeness of management ability and project quality.

Based on the discussion above, prior studies provide evidences on the existence of real earnings smoothing activities. The lack of empirical evidence on the role of real earnings smoothing, either as information signaling or garbling, summons for more research in this area. The role of accrual earnings smoothing is discussed in the following sections, as categorised into four factors: firm value, financing need, compensation contract and outsiders' intervention.

\subsection{Earnings smoothing and firm value}

Earnings smoothing is related to the increased in firm value via meeting earnings prediction (Goel \& Thakor, 2003; Graham et al., 2005; Kirschenheiter \& Melumad, 2002), and reducing investors and creditors' perception of firm's bankruptcy probability (Trueman \& Titman, 1988).

Under information signaling view, managers are expected to smooth earnings and report earnings that are close to investors' expectation or target. Smaller earnings surprise signals 
higher earnings quality of previously reported earnings (DeJong et al., 2014; Kirschenheiter \& Melumad, 2002), while managers inability to meet investors' expectation is perceived as a signal of hidden problems at the firm, for which the firm would be severely punished (Graham et al., 2005). Accordingly, Graham et al. (2005) find that managers are willing to sacrifice long-term value to meet earnings expectations.

In addition, investors abhor earnings volatility and pay less for firms with higher earnings volatility because it is associated with greater expected losses (Goel \& Thakor, 2003). Hence, they contend that investors want managers to smooth earnings as much as possible, so that future earnings are more predictible. Consistent with this argument, Di and Marciukaityte (2015) find that repurchasing firms use earnings smoothing to increase the predictability of reported earnings.

Further, Trueman and Titman (1988) argue that earnings smoothing may be able to reduce investors and creditors' expectation of firm's bankruptcy probability; hence they are willing to do transaction at lower costs. This would result in the increase of firm's value. In relation to this argument, empirical researches provide mix evidences where Lev and Kunitzky (1974) find evidence of earnings smoothing reducing firm's common stock risk while McInnis (2010) find no evidence on the relation between earnings smoothness and average stock returns shareholders of firms with volatile earnings are not compensated with higher returns.

Based on the literature discussed above, abundant theoretical and empirical researches have been trying to explain the role of earnings smoothing as information signaling, based on managers' incentives to maximize firm value. Future research may want to look into the effect of earnings smoothing on firm value in the long-term basis.

\subsection{Earnings smoothing and financing need}

The roles of financial reporting in debt contracting arise from two situations: (1) during the credit-granting decision stage and (2) during subsequent ongoing monitoring by creditors. During the credit-granting decision stage, lenders demand high quality financial reporting from firms to reduce their information risk in forecasting future cash flows. In addition, creditors also demand high-quality financing reporting to increase debt-contracting efficiency during subsequent ongoing monitoring.

Based on these two situations, the role of earnings smoothing as information signaling is stronger during credit-granting stage because firms need to signal credible financial information to lower their cost of debt. Consistent with this argument, Amiram and Owens (2017), Gassen and Fülbier (2015), and Li and Richie (2016) find that earnings smoothing is associated with lower cost of debt; creditors perceive smooth earnings as a signal of business stability and lower loan default risk. In addition, Jung et al. (2013) find that credit rating agencies also perceive earnings smoothing as a signal of business stability; managers reduce earnings volatility in order to improve or maintain credit ratings.

On the other hand, during ongoing monitoring of covenant compliance by creditors, the role of earnings smoothing as information garbling is stronger because firms may engage in earnings management to avoid breaching debt covenants. In support to this argument, Gassen 
and Fülbier (2015) find that firms with more credit report smoother earnings stream, to avoid debt-renegotiation and bankruptcy costs.

Nonetheless, the need to use earnings smoothing as information signaling is the strongest in the situation where information asymmetry between firm and creditors are very high, for example, in the countries with weak creditors' protection or specific industries where high information asymmetry exist. In these situations, earnings smoothing serves as information signaling, to mitigate agency problem of debt (Bigus \& Häfele, 2016; Dou et al., 2013). García-Teruel et al. (2014) find that SMEs (SMEs are characterized with high information asymmetry) with smoother earnings have more access to trade credit from suppliers.

While the researches on the role of earnings smoothing as information signaling, during credit-granting decision stage, are plenty, researches on its role as information garbling, during subsequent ongoing monitoring, is still lacking. Therefore, more researches in this area are warranted. In addition, future researches may be directed towards understanding the role of earnings smoothing in the situation where firms are in great need of finance, for example financially distressed firms.

\subsection{Earnings smoothing and compensation contract}

In line with information garbling theory, studies in executive compensation generally view earnings smoothing as an outcome of managers' opportunistic behavior; to maximize their current and future compensation, as well as to secure their job contracts (Fudenberg \& Tirole, 1995). Managers underreport earnings when realized earnings are sufficiently high, or when their bonus reaches the bonus cap, and the over-report earnings when realized earnings fall between a lower and upper bound of bonus (Defond \& Park, 1997; Grant et al., 2009; Healy, 1985; Spagnolo, 2005). However, when the realized earnings is really bad, they would engage in 'big bath' - managers underreport earnings by the maximum amount possible, in order to report higher and smoother earnings in the future (Kirschenheiter \& Melumad, 2002).

Hence, to mitigate managers incentives of using earnings smoothing as information garbling, manager inside debt may be used as a new compensation strategy (Dhole et al., 2016). Inside debt refers to use of debt as a portion of managers compensation, using defined benefit pensions and other deferred compensation, with the premise that managers' compensation is paid at or after retirement, as long as the firm in solvent. In the case of firm insolvency, managers would lose all these benefits.

Apart from managerial opportunism behavior, Das et al. (2013) find that earnings smoothing is partly induced by compensation contracts that reward managers for smoother earnings. They find that smooth earnings are used as a performance metric for manager compensation.

This relatively new findings summons for more researches to disentangle the role of earnings smoothing in compensation contract, whether they solely serve as information garbling for private benefits of managers, or they are actually part of managers duty, in which shareholders want managers to smooth earnings and that managers are being compensated for doing so. 


\subsection{Earnings smoothing and outsiders' intervention}

The theory of earnings smoothing as information garbling to avoid outsiders' intervention is a newly emerged theory, proposed by Acharya \& Lambrecht (2015). Based on asymmetric information theory, investor's estimate is unbiased and 'best' based on the information they have. Therefore, it is considered rational for shareholders to require earnings outcome that is consistent with their expectation. Outsiders may take collective action against insiders if they do not receive a fair payout that meets their expectations. Hence, managers need to report earnings that are close to shareholders' expectation, to keep them at bay.

In addition, since earnings smoothing held investors from intervening with management, managers are able to keep unprofitable projects, continue with ineffective risk management practice and withhold bad news. In line with this argument, Chen et al. (2017), Khurana et al. (2017) and Yu et al. (2017) find that managers use earnings smoothing as a mean to hide or withhold bad news from shareholders. As a consequence, firms are exposed to a greater stock price crash risk, especially when the accumulated bad news burst. These contemporary findings open up more opportunities for future research, for example, using other measures of firms' risk to examine the effect of earnings smoothing or, examining the effect of earnings smoothing in relation to industry-specific risks.

\section{Conclusion}

This paper reviews the literature on the role of earnings smoothing, either as information garbling or information signaling. Based on the literature discussed above, the role of earnings smoothing depends on how managers intend to use it, either to maximize firm value, avoiding outsiders' intervention, for personal gain or to get better debt covenant terms from creditors. While there are relatively plenty of researches have been examining the role of earnings smoothing, more researches are needed as highlighted below:

- While the role of earnings smoothing either as information signaling or garbling can generally be attributed into four factors (signaling: firm value and financing need; garbling: compensation contract and avoiding outsiders' intervention), the mixed evidences as found in the literature shows that more research is needed to better understand the role of earnings smoothing for each factor

- The role of earnings smoothing may not be attributed by a single factor. Rather, managers' decision to signal or garble information via earnings smoothing may be dependent on various factors at a time. Hence, future research may want to look at which factor dominates when multiple factors arise

- Prior researches rely solely on archival data in arriving at their findings. Future research should integrate analysis from both secondary and primary data source to get a more comprehensive picture of the role of earnings smoothing

- Majority of research on earnings smoothing are conducted in the US and European countries. Due to the different economic conditions, listing requirements, and 
government policies, more research should be conducted in countries with emerging economies

\section{References}

Acharya, V., \& Lambrecht, B. M. (2015). A Theory of Income Smoothing When Insiders Know More Than Outsiders. Review of Financial Studies, 28(9), 2534-2574. https://doi.org/10.1093/rfs/hhv026

Amiram, D., \& Owens, E. (2018). Sign Reversal in the Relation between Income Smoothing and Cost of Debt. Journal of Business Finance \& Accounting, 45(1-2), 40-71. https://doi.org/10.1111/jbfa.12295

Atik, A. (2009). Detecting Income-Smoothing Behaviors of Turkish Listed Companies through Empirical Tests using Discretionary Accounting Changes. Critical Perspectives on Accounting, 20(5), 591-613. https://doi.org/10.1016/j.cpa.2008.01.003

Beidleman, C. R. (1973). Income Smoothing: The Role of Management. The Accounting Review, 48(4), 653-667. http://www.jstor.org/stable/245289

Bhattacharya, U., Daouk, H., \& Welker, M. (2003). The World Price of Earnings Opacity. The Accounting Review, 78(3), 641-678. https://doi.org/10.2308/accr.2003.78.3.641

Bigus, J., Georgiou, N., \& Schorn, P. (2016). Legal Form and Earnings Properties. European Accounting Review, 25(3), 515-548. https://doi.org/10.1080/09638180.2015.1051566

Bigus, J., \& Häfele, S. (2016). Shareholder Loans and Earnings Smoothing - Empirical Findings from German Private Firms. European Accounting Review. https://doi.org/10.1080/09638180.2016.1229206

Boterenbrood, R. (2014). Income Smoothing by Dutch Hhospitals. Journal of Accounting and Public Policy, 33(5), 510-524. https://doi.org/10.1016/j.jaccpubpol.2014.06.005

Bouwman, C. H. S. (2014). Managerial Optimism and Earnings Smoothing. Journal of Banking and Finance, 41, 283-303. https://doi.org/10.1016/j.jbankfin.2013.12.019

Burgstahler, D. C., Hail, L., \& Leuz, C. (2006). The Importance of Reporting Incentives: Earnings Management in European Private and Public Firms. Accounting Review, 81(5), 983-1016. https://doi.org/10.2308/accr.2006.81.5.983

Chen, C., Kim, J. B., \& Yao, L. (2017). Earnings Smoothing: Does It Exacerbate or Constrain Stock Price Crash Risk? Journal of Corporate Finance, 42, 36-54. https://doi.org/10.1016/j.jcorpfin.2016.11.004

Das, S., Hong, K., \& Kim, K. (2013). Earnings Smoothing, Cash Flow Volatility, and CEO Cash Bonus. Financial Review, 48(1), 123-150. https://doi.org/10.1111/j.1540-6288.2012.00349.x

Dechow, P., Ge, W., \& Schrand, C. (2010). Understanding Earnings Quality: A Review of the Proxies, Their Determinants and Their Consequences. Journal of Accounting and Economics, 
50(2-3), 344-401. https://doi.org/10.1016/j.jacceco.2010.09.001

Defond, M. L., \& Park, C. W. (1997). Smoothing Income in Anticipation of Future Earnings. Journal of Accounting and Economics, 23(2), 115-139. https://doi.org/10.1016/S0165-4101(97)00004-9

DeJong, A., Mertens, G., Van Der Poel, M., \& Van Dijk, R. (2014). How Does Earnings Management Influence Investor's Perceptions on Firm Value? Survey Evidence from Financial Analysts. Review of Accounting Studies, 19(2), 606-627. https://doi.org/10.1007/s11142-013-9250-y

Dhole, S., Manchiraju, H., \& Suk, I. (2016). CEO Inside Debt and Earnings Management. Journal of Accounting, Auditing and Finance, 31(4), 515-550. http://doi.org/10.1177/0148558X15596907

Di, H., \& Marciukaityte, D. (2015). Earnings Smoothing around Open-Market Share Repurchases. Review of Accounting and Finance, 14(1), 64-80. https://doi.org/10.1108/RAF-10-2012-0111

Dou, Y., Hope, O. K., \& Thomas, W. B. (2013). Relationship-Specificity, Contract Enforceability, and Income Smoothing. The Accounting Review, 88(5), 1629-1656. https://doi.org/10.2308/accr-50489

Erickson, D., Hewitt, M., \& Maines, L. A. (2017). Do Investors Perceive Low Risk when Earnings are Smooth Relative to the Volatility of Operating Cash Flows? Discerning Opportunity and Incentive to Report Smooth Earnings. Accounting Review, 92(3), 137-154. https://doi.org/10.2308/accr-51568

Ewert, R., \& Wagenhofer, A. (2015). Economic Relations among Earnings Quality Measures. Abacus, 51(3), 311-355. https://doi.org/10.1111/abac.12054

Francis, B., Hasan, I., \& Li, L. (2016). Evidence for the Existence of Downward Real-Activity Earnings Management. Journal of Accounting, Auditing and Finance, 31(2), 212-248. https://doi.org/10.1177/0148558X15582086

Fudenberg, D., \& Tirole, J. (1995). A Theory of Income and Dividend Smoothing Based on Incumbency Rents. Journal of Political Economy, 103(1), 75-93. https://doi.org/10.1086/261976

García-Teruel, P. J., Martínez-Solano, P., \& Sánchez-Ballesta, J. P. (2014). Supplier Financing and Earnings Quality. Journal of Business Finance and Accounting, 41(9-10), 1193-1211. https://doi.org/10.1111/jbfa.12090

Gassen, J., \& Fülbier, R. U. (2015). Do Creditors Prefer Smooth Earnings? Evidence from European Private Firms. Journal of International Accounting Research, 14(2), 151-180. https://doi.org/10.2308/jiar-51130

Gassen, J., Fulbier, R. U., \& Sellhorn, T. (2006). International Differences in Conditional Conservatism - The Role of Unconditional Conservatism and Income Smoothing. European 
Accounting Review, 15(4), 527-564. https://doi.org/10.1080/09638180601102107

Gill de Albornoz, B., \& Alcarria, J. J. (2003). Analysis and Diagnosis of Income Smoothing in Spain. European Accounting Review, 12(3), 443-463. https://doi.org/10.1080/0963818022000001154

Goel, A. M., \& Thakor, A. V. (2003). Why Do Firms Smooth Earnings? Journal of Business, 76(1), 151-192. http://www.jstor.org/stable/10.1086/344117

Graham, J. R., Harvey, C. R., \& Rajgopal, S. (2005). The Economic Implications of Corporate Financial Reporting. Journal of Accounting and Economics, 40(1), 3-73. https://doi.org/10.1016/j.jacceco.2005.01.002

Grant, J., Markarian, G., \& Parbonetti, A. (2009). CEO Risk-Related Incentives and Income Smoothing. Contemporary Accounting Research, 26(4), 1029-1065. https://doi.org/10.1506/car.26.4.2

Healy, P. (1985). The Effect of Bonus Schemes on Accounting Decisions. Journal of Accounting and Economics, 7(1-3), 85-107. https://doi.org/10.1016/0165-4101(85)90029-1

Hepworth, S. R. (1953). Smoothing Periodic Income. The Accounting Review, 28(1), 32-39. http://www.jstor.org/stable/241436

Houcine, A. (2017). The Effect of Financial Reporting Quality on Corporate Investment Efficiency: Evidence from the Tunisian Stock Mmarket. Research in International Business and Finance, 42(July), 321-337. https://doi.org/10.1016/j.ribaf.2017.07.066

Huang, P., Zhang, Y., Deis, D. R., \& Moffitt, J. S. (2009). Do Artificial Income Smoothing and Real Income Smoothing Contribute to Firm Value Equivalently? Journal of Banking and Finance, 33(2), 224-233. https://doi.org/10.1016/j.jbankfin.2008.07.012

Huang, Z., \& Xue, Q. (2016). Re-Examination of the Effect of Ownership Structure on Financial Reporting: Evidence from Share Pledges in China. China Journal of Accounting Research, 9(2), 137-152. https://doi.org/10.1016/j.cjar.2015.11.001

Jung, B., Soderstrom, N., \& Yang, Y. S. (2013). Earnings Smoothing Activities of Firms to Manage Credit Ratings. Contemporary Accounting Research, 30(2), 645-676. https://doi.org/10.1111/j.1911-3846.2012.01170.x

Khalil, M., \& Simon, J. (2014). Efficient Contracting, Earnings Smoothing and Managerial Accounting Discretion. Journal of Applied Accounting Research, 15(1), 100-123. https://doi.org/10.1108/JAAR-06-2012-0050

Khurana, I. K., Pereira, R., \& Zhang, E. (2017). Is Real Earnings Smoothing Harmful? Evidence from Firm-Sspecific Stock Price Crash Risk. Contemporary Accounting Research. https://doi.org/10.1111/ijlh.12426

Kirschenheiter, M., \& Melumad, N. D. (2002). Can "Big Bath" and Earnings Smoothing Co-Exist as Equilibrium Financial Reporting Strategies? Journal of Accounting Research, 40(3), 761-796. https://doi.org/10.1111/1475-679X.00070 
Lambert, R. A. (1984). Income Smoothing as Rational Equilibrium Behavior. The Accounting Review, 59(4), 604-618. http://www.jstor.org/stable/247322

Leuz, C., Nanda, D., \& Wysocki, P. D. (2003). Earnings Management and Investor Protection: An International Comparison. Journal of Financial Economics, 69(3), 505-527. https://doi.org/10.1016/S0304-405X(03)00121-1

Lev, B., \& Kunitzky, S. (1974). On the Association between Smoothing Measures and the Risk of Common Stocks. The Accounting Review, 49(2), 259-270. http://www.jstor.org/stable/245100

Li, S., \& Richie, N. (2016). Income Smoothing and the Cost of Debt. China Journal of Accounting Research, 9(3), 175-190. https://doi.org/10.1016/j.cjar.2016.03.001

McInnis, J. (2010). Earnings Smoothness, Average Returns, and Implied Cost of Equity Capital. The Accounting Review, 85(1), 315-341. https://doi.org/10.2308/accr.2010.85.1.315

Safdar, R., \& Yan, C. (2016). Managing Accruals for Income Smoothing: Empirical Evidence from Pakistan. Journal of Accounting in Emerging Economies, 6(4), 372-387. https://doi.org/10.1108/JAEE-07-2014-0038

Sankar, M. R., \& Subramanyam, K. R. (2001). Reporting Discretion and Private Information Communication through Earnings. Journal of Accounting Research, 39(2), 365-386. https://doi.org/10.1111/1475-679X.00017

Shubita, M. F. (2015). The Impact of Income Smoothing on Earnings Quality in Emerging Markets: Evidence from GCC Markets. Journal of Accounting in Emerging Economies, 5(3), 299-324. https://doi.org/10.1108/JAEE-04-2011-0011

Shuto, A., \& Iwasaki, T. (2014). Stable Shareholdings, the Decision Horizon Problem and Earnings Smoothing. Journal of Business Finance and Accounting, 41(9 \& 10), 1212-1242. https://doi.org/10.1111/jbfa.12091

Silhan, P. A. (2014). Interfirm Differences in Earnings Variability: An Analysis of Fundamentals, Cash Flows and Accruals. Accounting and Finance, 54(4), 1357-1379. https://doi.org/10.1111/acfi.12038

Spagnolo, G. (2005). Managerial Incentives and Collusive Behavior. European Economic Review, 49(6), 1501-1523. https://doi.org/10.1016/j.euroecorev.2004.05.003

Subramanyam, K. R. (1996). The Pricing of Discretionary Accruals. Journal of Accounting and Economics, 22(1-3), 249-281. https://doi.org/10.1016/S0165-4101(96)00434-X

Trueman, B., \& Titman, S. (1988). An Explanation for Accounting Income Smoothing. Journal of Accounting Research, 26, 127-139. http://www.jstor.org/stable/2491184

Tucker, J. W., \& Zarowin, P. A. (2006). Does Income Smoothing Improve Earnings Informativeness? The Accounting Review, 81(1), 251-270. https://doi.org/10.2308/accr.2006.81.1.251 


\section{Macrothink}

Asian Journal of Finance \& Accounting ISSN 1946-052X 2018, Vol. 10, No. 1

Yu, K., Hagigi, M., \& Stewart, S. D. (2017). Income Smoothing May Result in Increased Perceived Riskiness: Evidence from Bid-Ask Spreads around Loss Announcements. Journal of Corporate Finance. https://doi.org/10.1016/j.jcorpfin.2017.11.007

\section{Copyright Disclaimer}

Copyright for this article is retained by the author(s), with first publication rights granted to the journal.

This is an open-access article distributed under the terms and conditions of the Creative Commons Attribution license (http://creativecommons.org/licenses/by/3.0/). 